\title{
White-Tailed Deer of Florida ${ }^{1}$
}

\section{Raoul K. Boughton, Bethany Wight, Samantha Wisely, Karen Hood, and Martin B. Main ${ }^{2}$}

This document contains an overview of the deer populations of Florida as well as their history and contemporary management issues. You may also be interested in the Wildlife of Florida Factsheet: White-tailed Deer, which can be found at https://edis.ifas.ufl.edu/UW445.

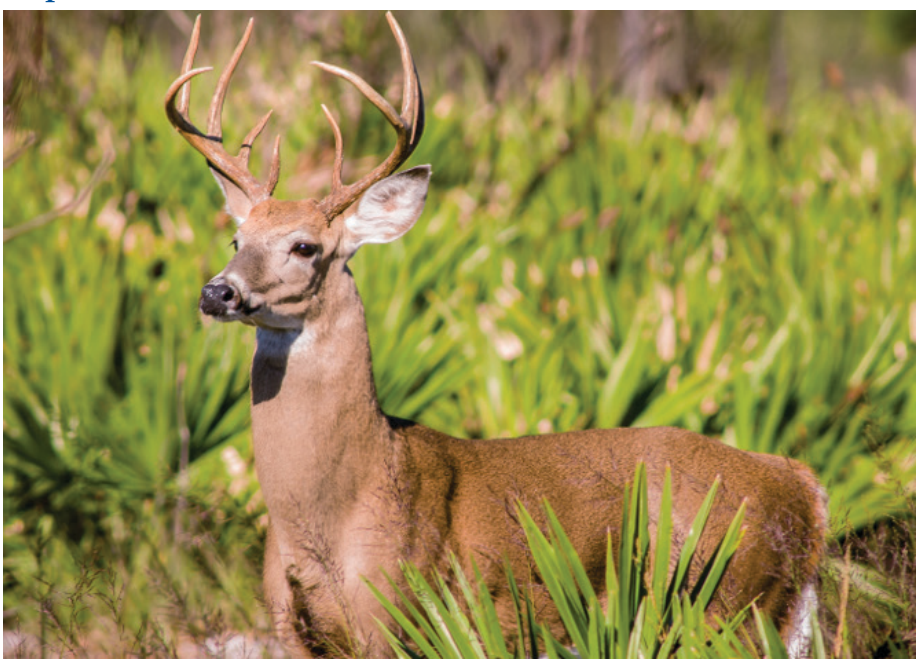

Figure 1. A mature male white-tailed deer, typically called a buck. Credits: Reed Bowman

\section{Background}

The white-tailed deer (Odocoileus virginianus) is the most economically important big game mammal in North America and Florida. In 2011, over $\$ 50$ billion was spent on deer hunting in the United States. In Florida, deer hunting generated \$95 million dollars in state and local taxes and generated 14,673 jobs in 2011. Florida deer are also a major prey species for the endangered Florida panther (Puma concolor coryi). As a consequence, deer have been the object of much management, research, and controversy.

Within the past century, Florida's deer herd has gone through many changes. Throughout Florida, unregulated trade in deer hides and subsistence hunting during the mid1700 s caused deer populations to decline sharply. In 1828, a law prohibiting firearm hunting west of the Suwannee River was passed to help restore population levels. However, a deer removal campaign to eradicate the cattle-fever tick in the 1930s and 40s reduced the population to an estimated 20,000. The campaign ended in 1941 with the enactment of the Pittman-Robertson Act, a federal tax on firearms and ammunition that aided in funding wildlife conservation, hunter education, and shooting programs. Arrests for game violations in the 1940s and the eradication of the screwworm fly in 1958 also helped deer populations begin to recover. The Florida Game and Fresh Water Fish Commission (GFC) (now known as the Florida Fish and Wildlife Conservation Commission [FWC]) also promoted recovery by purchasing deer from various sources, including a game farm in Wisconsin and states such as Texas, Louisiana, and Pennsylvania, and then transplanting them to unoccupied areas in Florida. Killing adult females (does) was also prohibited during the early restocking period to further ensure success. These efforts were successful and although the state herd size is not exactly known, it is large and now sustains a harvest of $\sim 97,000$ deer per year.

1. This document is WEC133, one of a series of the Department of Wildlife Ecology and Conservation, UF/IFAS Extension. Original publication date June 1997. Revised August 2001, December 2014, and December 2019. Visit the EDIS website at https://edis.ifas.ufl.edu for the currently supported version of this publication.

2. Raoul K. Boughton, assistant professor; and Bethany Wight, research biologist; Department of Wildlife Ecology and Conservation, UF/IFAS Range Cattle Research and Education Center; Samantha Wisely, professor, Department of Wildlife Ecology and Conservation; Karen Hood, MS student, Department of Wildlife Ecology and Conservation; and Martin B. Main, associate dean and Extension program leader, natural resources and Florida Sea Grant; UF/IFAS Extension, Gainesville, FL 32611. Joe Schaefer, professor, contributed to an earlier version of this publication.

The Institute of Food and Agricultural Sciences (IFAS) is an Equal Opportunity Institution authorized to provide research, educational information and other services

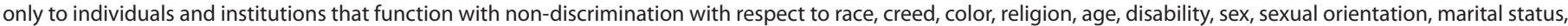

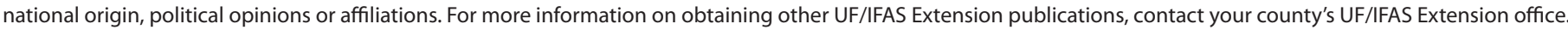
U.S. Department of Agriculture, UF/IFAS Extension Service, University of Florida, IFAS, Florida A \& M University Cooperative Extension Program, and Boards of County Commissioners Cooperating. Nick T. Place, dean for UF/IFAS Extension. 


\section{Taxonomy and Distribution}

The white-tailed deer is one of 171 species in the taxonomic order Artiodactyla, which means "even-toed." The hooves are actually toenails of the third and fourth toes of each foot, and support the animal's entire weight. Other species in Artiodactyla include various other deer, camels, oxen, hippopotamuses, and pigs.

Within Artiodactyla, 37 species belong to the family Cervidae, known as true deer, which share such characteristics as only males having antlers (except in one species). The antlers of true deer are deciduous, meaning shed annually (except in two species); the same dental arrangement; reduced second and fifth toes; and a four-chambered, ruminating stomach.

In addition to deer, North American examples within the family Cervidae include elk (Cervus elaphus), moose (Alces alces), and caribou (Rangifer tarandus). The two most closely related deer species are white-tailed and mule deer (O. hemionus), both of which belong to the genus Odocoileus, which means "hollow tooth." White-tailed deer are widely distributed in North, Central, and South America ranging from 60 degrees north latitude near the Arctic Circle in Canada, to 18 degrees south latitude in Peru. There are 30 subspecies of white-tailed deer, of which three are found in Florida: the Florida coastal white-tailed deer (O. v. osceola), which occurs primarily in the Florida panhandle; the Florida white-tailed deer (O. v. seminolus) which occurs in peninsular Florida; and the Florida Key deer, with a distribution limited to Big Pine Key in the southern Florida keys (see Figure 2).
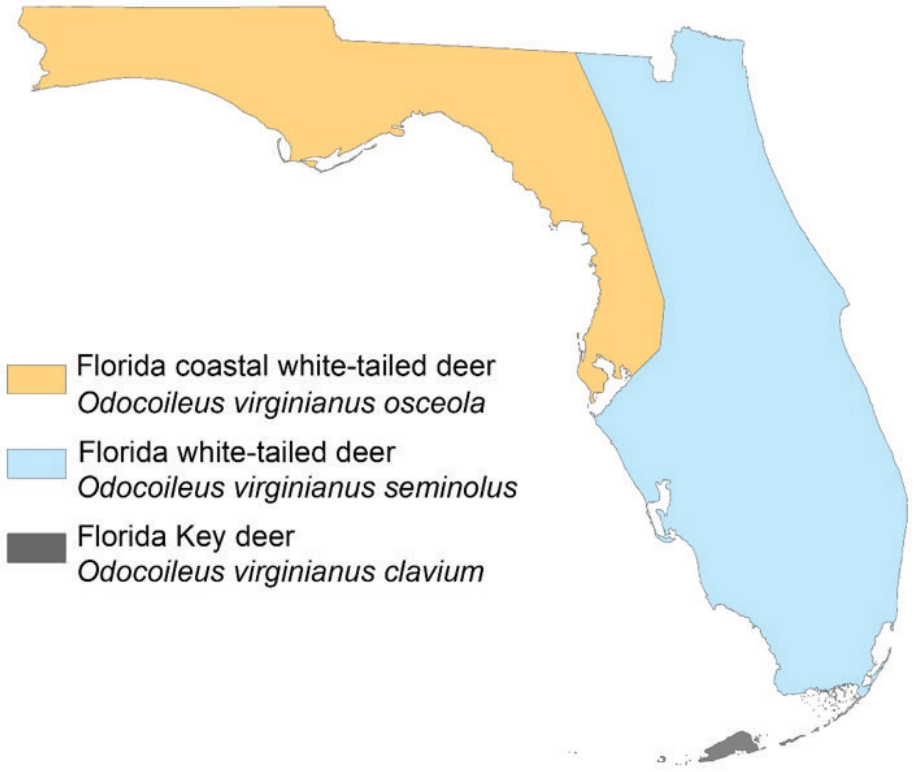

Figure 2. Range of white-tailed deer in Florida. Credits: UF/IFAS
Florida Key deer (O.v. clavium) are an endangered subspecies of white-tailed deer that only exists in the Florida Keys. Their ancestors are thought to have crossed to the Keys via a land bridge when sea levels were lower. Geographic isolation on islands led to local adaptation, and key deer became the smallest subspecies in North America, with males weighing a mere $\sim 80 \mathrm{lbs}$ and females $\sim 65 \mathrm{lbs}$, which is just above half the weight of a typical white-tailed deer (Figure 3). Key deer have high saltwater tolerance and low birth rates, and they are more solitary than white-tailed deer in other areas. Due to hunting and habitat loss, only 25 Key deer existed in 1955. Conservation efforts, including a complete hunting ban (1939) and the establishment of the National Key Deer Refuge (1967), have helped Key deer populations to increase to 700-800 individuals. In 2016-2017, a screwworm epidemic killed about $10 \%$ of the population; however, the population recovered due to relatively quick eradication of the screwworm flies and because mainly male deer were impacted. However, continued habitat loss and degradation and sea-level rise are still major risks to the population. The remainder of this document focuses mostly on white-tailed deer in other regions of Florida.

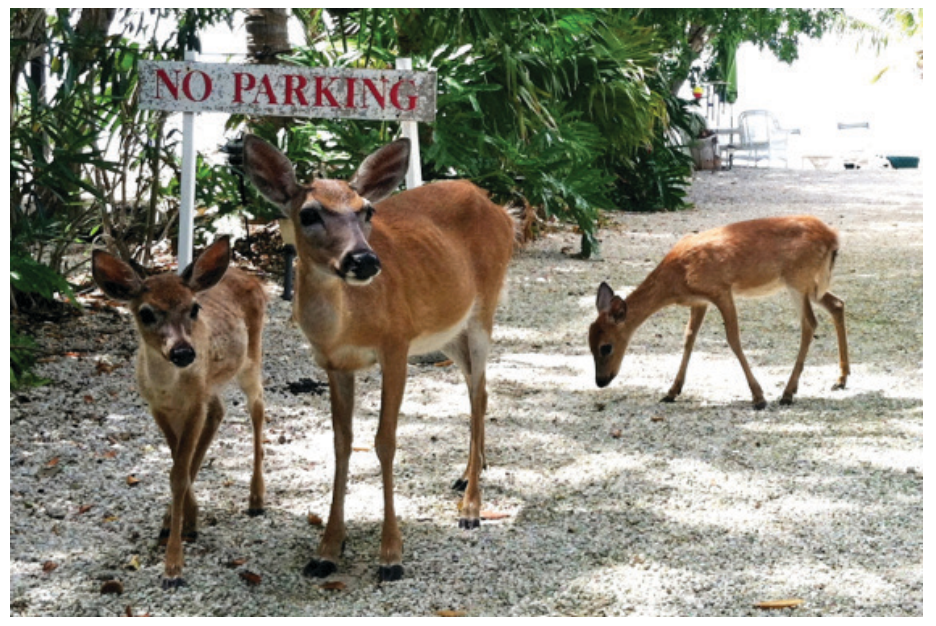

Figure 3. Florida key deer.

Credits: Kristin Lajeunesse

\section{Description}

\section{Age}

Life expectancy of deer is primarily influenced by hunting pressure and other mortality factors, such as predation, vehicle collision, and disease. Although 20 -year-old whitetailed deer have been documented, deer surviving beyond 6 years typically represent a small proportion of the herd, especially for males in heavily hunted populations. 


\section{Coloration}

The coloration of white-tailed deer aids in their camouflage, thermoregulation (a process that maintains their internal temperature), and even communication. Coloration and appearance of the pelage (coat) changes with seasonal molts, with summer coats being thinner and lighter to help deer stay cool. Although a great deal of individual and sub-specific variation exists in the coloration of white-tailed deer throughout their range, all tend to be cryptically colored in various shades of reddish-brown to grey-brown to even black.

The throat, belly, rump, and the underside of the tail are white, as are the insides of the ears. When white-tailed deer sense danger, the tail is held upright exposing the white tail underside and rump, for which they are named. This conspicuous reaction known as "flagging" quietly alerts other deer nearby and may also signal to the predator they have been spotted. The white flag of the doe's tail also serves as a beacon that guides her fawns as they try to follow in dimly lit forests. During their first 3-4 months, fawns have spotted coats that provide excellent camouflage. This spotted pelage disappears and is replaced by the adult brown coat at about the same time the fawn is weaned (Figure 4). True albino white-tailed deer with white coats and pink eyes are exceedingly rare under natural conditions. Partially white or "piebald" deer occur more commonly than albinos, but still at a frequency of less than 1 percent.

\section{Size}

Whitetails tend to be larger in the colder northern states, a tendency seen in many animals known as Bergmann's rule. An adult white-tail buck (male) from northern states may exceed $90 \mathrm{~kg}(200 \mathrm{lbs})$ and stand $100 \mathrm{~cm}$ (40 in) at the shoulder; a typical adult buck from Florida weighs about $56 \mathrm{~kg}(125 \mathrm{lbs})$ and the average adult female (doe) weighs about $43 \mathrm{~kg}(95 \mathrm{lbs})$. Adult Florida deer are about $90 \mathrm{~cm}(36$ in) tall. Deer in southern Florida tend to be smallest. The Florida Key deer is one of the smallest of all 30 subspecies of white-tailed deer. They typically weigh less than $39 \mathrm{~kg}$ (80 lbs) with a shoulder height of about $70 \mathrm{~cm}$ (27 in). Only the Coiba Island white-tailed deer (O. v. rothschildi), which occurs off the Pacific Coast of Panama, is smaller.

\section{Antlers}

Antlers are a fascinating component of deer anatomy (see Figure 5). Typically, only bucks grow antlers. This is because the male hormone, testosterone, is the primary hormone that controls antler growth. However, there also are documented cases of does with antlers, although these are rare.
The most important function of antlers is as an indicator of which males will be the most successful to breed with, and occurs through male-male combat and female mate choice (See Courtship and Reproduction).

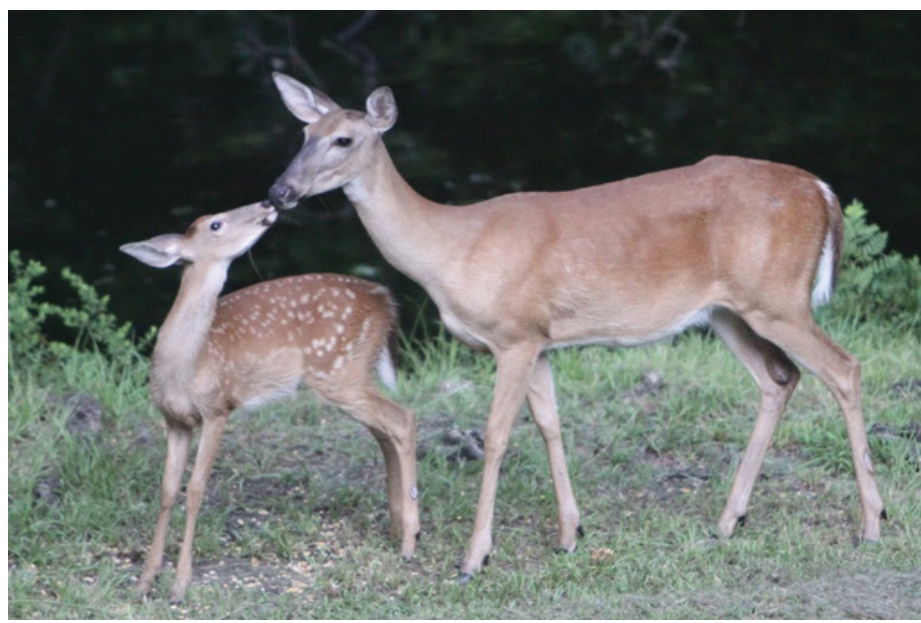

Figure 4. A fawn (left) and female or doe (right) white-tailed deer. Credits: Dennis Adair

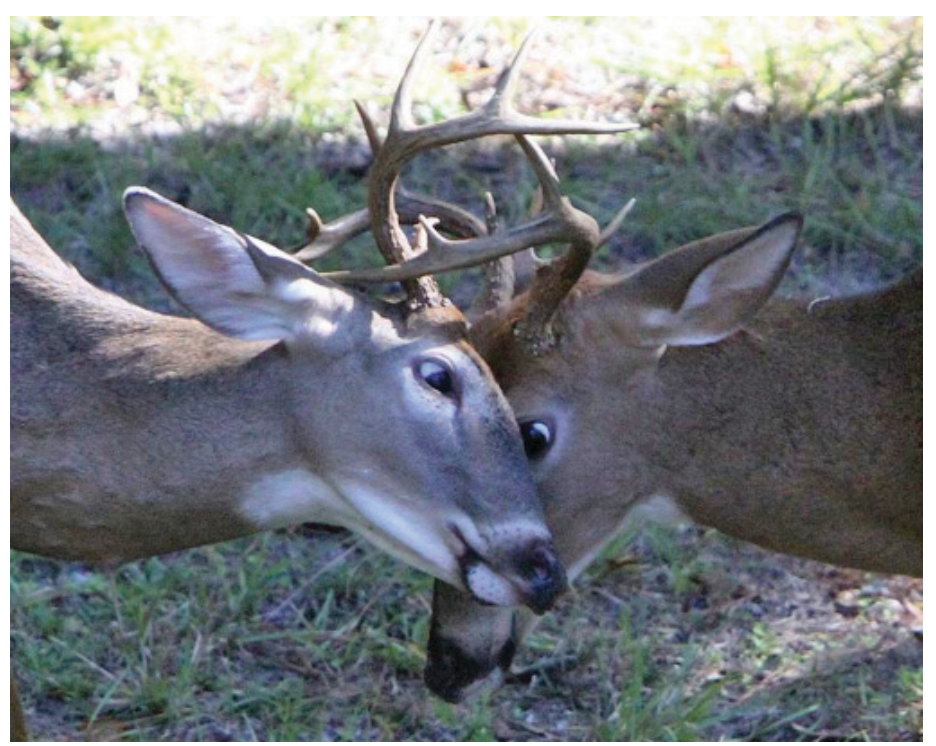

Figure 5. White-tailed deer bucks sparring and locking antlers during rut.

Credits: Dennis Adair

Antlers are not true horns but outgrowths that originate from frontal bones on the skull know as pedicels. They are used as an indicator of quality in sexual selection. Unlike true horns (which are permanent structures), antlers are shed every year and must be regrown at considerable expenditure of energy. Antler growth is one of the fastest types of mammalian tissue growth, growing up to $1 / 4$ inch per day.

The timing of rut of Florida white-tailed deer is the widest ranging of any state, starting in July for south Florida to early March in northwest Florida. Antlers are typically shed during the winter (Figure 6) and the formation of new ones 
seems to be linked to day-length, with new growth forming as days start becoming longer (which is usually a couple of weeks after the old ones are dropped). Cast antlers are seldom found in the woods because rodents gnaw them and Florida's humid, warm climate enhances their deterioration.

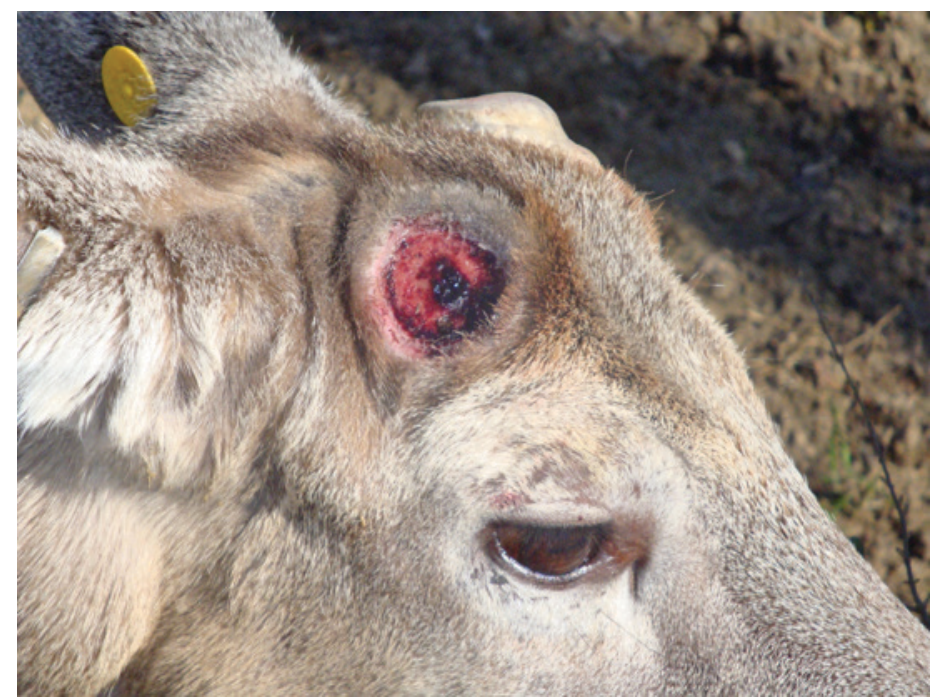

Figure 6. White-tailed deer one day after antlers were shed.

Credits: Steve Demarais, MSU

Antlers typically begin growing in the spring, shortly after the previous set is cast. New antlers possess a velvet- like covering that provides a blood supply carrying essential minerals (Figure 7). During this growing, or velvet stage, antlers are very sensitive and if injured will bleed profusely. After about 5 months and just before the mating season, the blood supply terminates and the velvet dries and is shed as the deer rubs the antlers against trees and shrubs. This period is when the antlers become hard, sharp weapons.

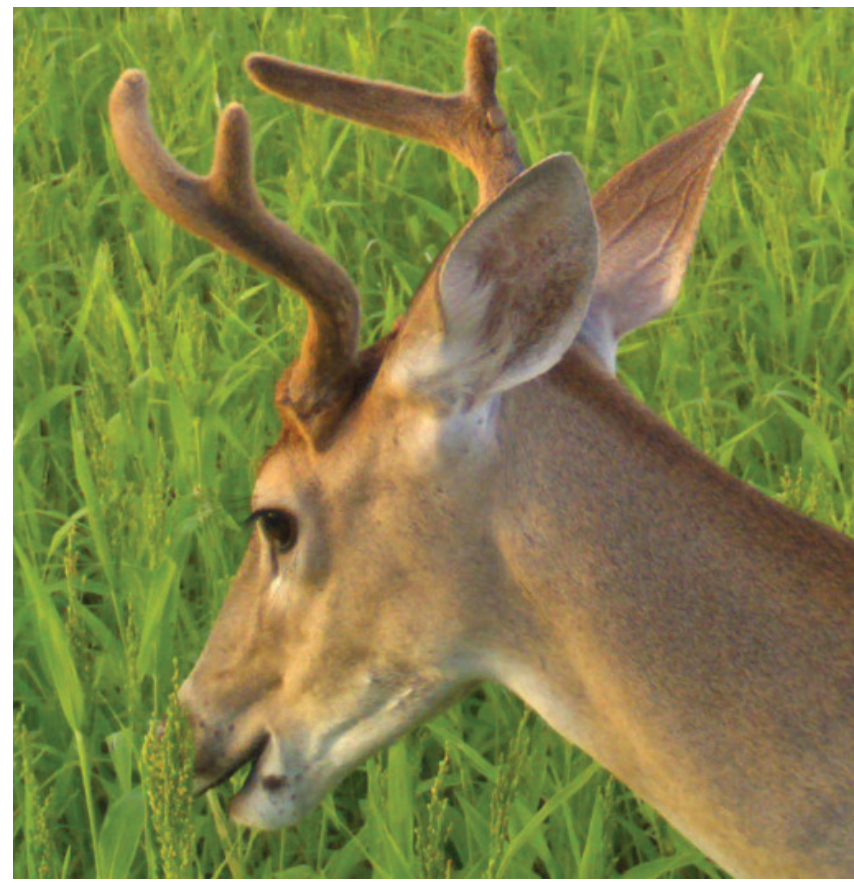

Figure 7. White-tailed deer with "velvet"-covered antlers. Credits: UF/IFAS
The size of antlers is influenced by genetic factors, nutrition, and the age of the animal. Antlers generally increase in size (up to a point) as the deer gets older. A young "button buck" born during the spring or summer will have antlers only about $2.5 \mathrm{~cm}$ ( $1 \mathrm{in})$ long during its first fall. In yearling bucks (16 to 18 months old), antlers tend to occur as spikes, although animals on nutritious forage may have forked antlers as yearlings.

Mature bucks typically have branched antlers and an average buck about four years of age often will have eight points, although this can vary greatly depending on the area and nutritional condition. Antlers of old bucks that are past their prime may become smaller and may form abnormally. Due to the variability in antler formation among deer of the same age and due to nutritional effects on antler growth, the size of a deer's antlers is not an accurate indication of age. Measurements of tooth eruption and tooth wear are much more reliable aging indicators.

Asymmetry in antlers is common with the left and right antler being slightly different from one another. It is thought that drastic differences in symmetry are caused by the inability of animal to cope with environmental stress such as sickness, injury, and low nutrition. Symmetrical antlers may indicate the animal has the genetic ability to cope with these environmental stressors, which again is an indicator of quality in sexual selection. Antler abnormalities or asymmetry are most commonly a result of damage to the pedicle (where the antler is connected to the skull), damage to the antler during the velvet stage or even a leg injury (Figures 8, 9, and 10). Injuries like this are seen more often in older bucks because they are typically more aggressive during the rut. Observations of injuries to a buck's hind leg have been associated with abnormalities in the growth of the opposite side antler.

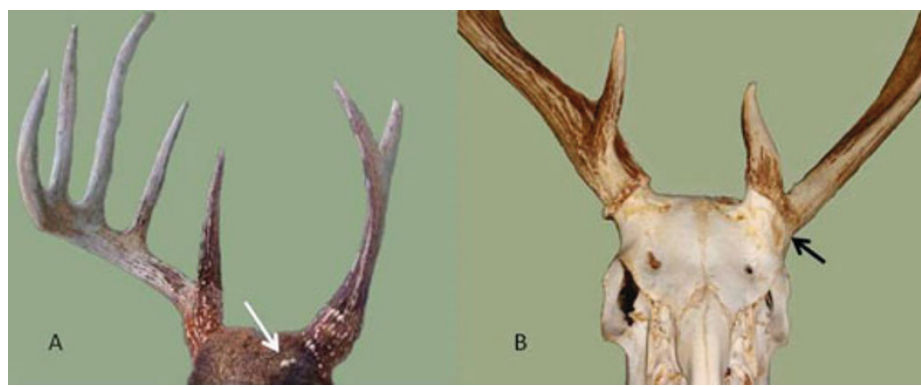

Figure 8. A presumptive injury caused asymmetry and growth of accessory antler (arrow) (A) and asymmetry, lack of burr and malformed pedicle indicative of trauma (B).

Credits: Mississippi State University Deer Lab 


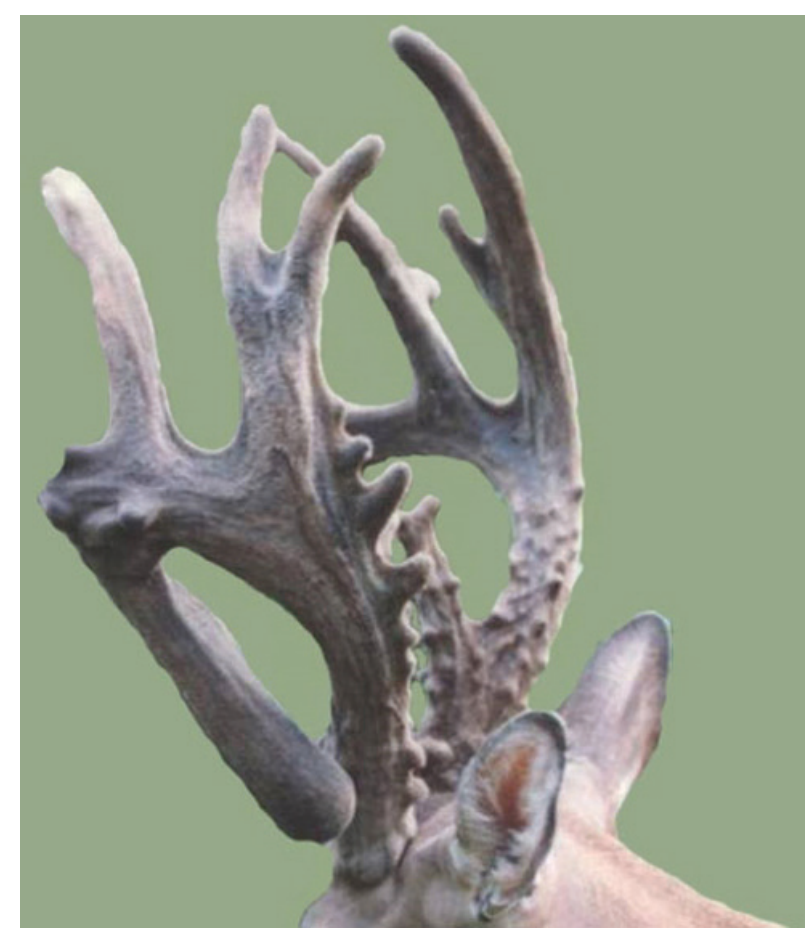

Figure 9. Broken beam as a result of damage to antler during velvet stage that maintained blood supply, survived, and hardened into abnormal conformation.

Credits: Mississippi State University Deer Lab

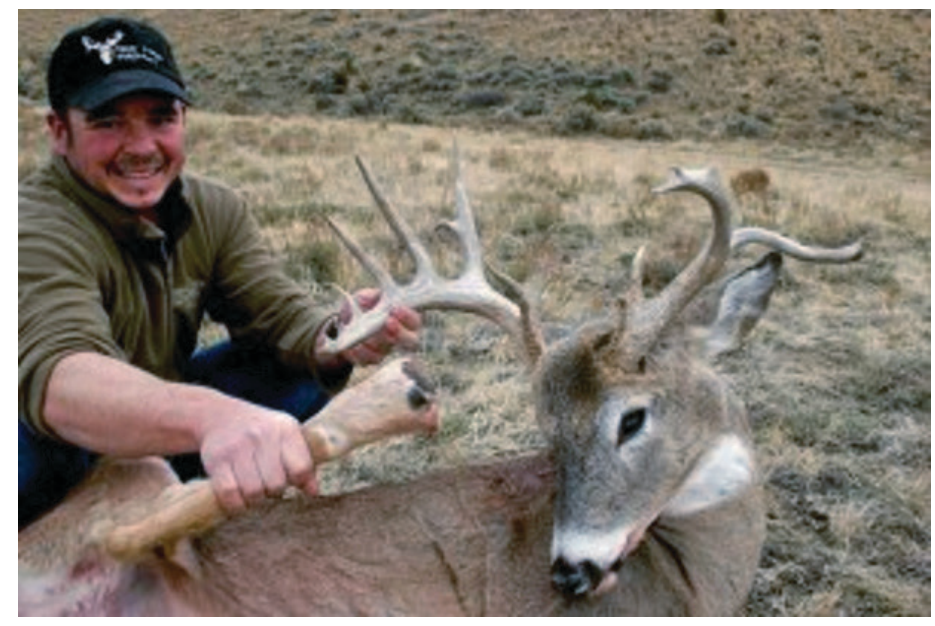

Figure 10. Severed right hind leg resulting in asymmetry in opposite left antler.

Credits: Ron Spomer Outdoors, https://ronspomeroutdoors.com/

\section{Sounds}

Although deer have several different calls, compared to smell and visual cues, vocalizations play a relatively minor role in deer communication. Sounds that are important include bleating or "mewing" by fawns which are used to summon their does.

Fawns will bawl when in extreme danger which will often elicit an aggressive defense by the doe. Bucks will also occasionally bleat or grunt when chasing does during rut. The most familiar deer-sounds are the grunts, snorts and foot-stomping used as alarm calls by a disturbed or frightened animal.

\section{Senses}

Deer are typically crepuscular in their activity patterns. This means they are most active during periods of dawn and dusk. However, in south Florida, deer are actually most active during the day. This shift is likely due to the increased risk of predation from panthers during the night and crepuscular periods. As an adaptation to this lifestyle in wooded areas where visibility is limited, deer have excellent senses of smell and hearing. Their keen sense of smell is vital in all aspects of safety, feeding, raising young, and mating. Their sense of hearing is also extremely important for detecting danger and communicating with other deer. The eyesight of deer is also well-suited to their lifestyle, with eyes adapted to detect motion and to see in low levels of light. Deer eyes are also well-adapted to function at a wide range of ambient light, including full daylight and are able to distinguish blue to yellow-green colors and even some orange and reds.

\section{Habitat}

The availability of suitable food, cover, water, and space defines the quality of habitat, which influences the carrying capacity for deer in the area. The carrying capacity is the maximum population size of an organism that the environment can support given the available resources in the area. Soil type and richness influences food quality and vegetation structure, which defines an area's habitat quality. The sandy soils found in most of Florida are nutrient-poor and do not provide high-quality forage throughout the year. Consequently, these lands support relatively low densities of deer except in areas modified by agricultural practices, which tend to provide deer with a nutritious supply of forage.

Deer usually reach highest densities where the woody cover is at least as much as the open grassland. They thrive in agricultural areas interspersed with woodlots and riparian habitats. They favor early successional stages (e.g., younger forests) that keep brush and sapling foods within reach. In areas such as the Everglades, deer populations can fluctuate greatly due to changes in the availability of suitable habitat. For example, the hundreds of thousands of acres of deer habitat in the Everglades can shrink to almost nothing during floods. This reduces the carrying capacity and concentrates deer on high ground, where many animals eventually die of starvation. 
The average annual home range size for adult females is about $250 \mathrm{ha}(1.0 \mathrm{mi} 2)$, and $650 \mathrm{ha}(2.5 \mathrm{mi} 2)$ for yearling and adult males. Does' largest monthly home range size in north Florida occurs in October during the peak of the rut. Bucks in the same area begin to move over larger areas in July and maintain their expanded home ranges through October. Deer with relatively large home range sizes commonly occur in habitats of poorer quality. They simply have to travel farther to obtain sufficient food resources. Yearling males may travel up to $10 \mathrm{~km}(6 \mathrm{mi})$ from their natal areas to establish new ranges. After this dispersal period, most deer show a strong lifetime fidelity to their settling site.

\section{Food}

Florida deer eat about $1.8 \mathrm{~kg}$ ( $4 \mathrm{lbs}$ ) of food ( $3 \%$ of their body weight) each day. Like cattle, deer process their food through a complex, 4-chambered ruminant stomach and 20 $\mathrm{m}$ (65 feet) of intestines. It takes 24 to 36 hours for food to pass completely through them.

The first and largest of these chambers is the rumen. It does not produce acid like a true stomach. Instead, the rumen acts as a holding tank full of microbes that digest most of the plant material and make the nutrients available to the deer. The relatively small rumen in deer requires more nutritious and easily digested forage than is required by cattle, which possess a large rumen. Consequently, deer are highly selective feeders.

Their diet consists of leaves and tender tips of many woody shrubs and vines, succulent green plants, grasses, acorns, mushrooms, aquatic plants and many other types and parts of plants within about $1.5 \mathrm{~m}(5 \mathrm{ft})$ above the ground. Due to their selective feeding habits, deer can change the relative abundance of plant species in an area. As their favorite foods become less available, their diets gradually shift to less nutritious and less preferred foods, which can have an adverse effect on reproductive success. Mast, especially acorns, is an important winter food source for deer. Competition for mast with other species such as introduced feral swine (Sus scrofa) could impact the condition and survival of deer.

The theory that supplemental feed will improve antler growth of deer in a certain area is questionable. One north Florida study showed that they visited feeders infrequently and yearling males dispersed so far that many were not on the same property during the fall hunt. However, supplemental feeding may benefit does and increase productivity of a local deer population (Figure 11). In agricultural settings, the whole system is acting as supplemental feed, and the critical time for deer is when these resources are low during the winter season. This effect would be magnified if local winter resources such as mast were limited. For more information on supplemental feeding and food plots see https://edis.ifas.ufl.edu/uw262 and http://edis.ifas.ufl. $\mathrm{edu} / \mathrm{fr} 167$.

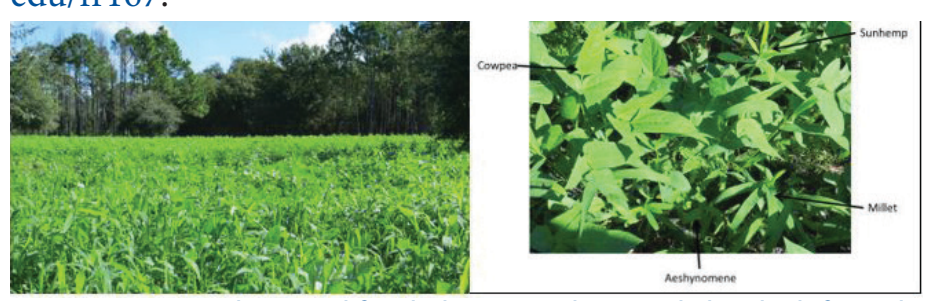

Figure 11. A supplemental food plot in south central Florida (left) and species planted (right).

Credits: UF/IFAS

\section{Courtship and Reproduction}

The breeding season (also called the "rut") consists of several phases extending over 3 or 4 months, starting with sparring activity among bucks (as soon as the antler velvet falls off) and ending after mating.

Sparring matches are mildly aggressive encounters that are actually pushing contests that seem to help establish a hierarchy or pecking order before the actual breeding phase. Courtship or chasing of does by bucks begins about 4 to 6 weeks after the onset of sparring. During the courtship phase, aggressive signals between bucks are common. Usually, one of the two will assume a submissive posture and turn away from the more dominant buck. However, when two males are equally matched and visual displays fail to dissuade one of the suitors, they will lower their heads and charge each other, lock antlers and push until one is driven back and forced to retreat. Occasionally, these battles result in serious injury to one or both combatants. Although most antler fights do not last more than 30 seconds, they become more fierce and aggressive as more does come into estrus and mating rights are at stake for the bucks. Only rarely do two bucks permanently lock antlers while fighting and perish from exhaustion or starvation because they cannot separate from one another.

In temperate zones, rut behavior of males is highly synchronized and triggered by the shortening day lengths in late fall. However, in Florida and other southern latitudes (such as Texas and Venezuela), breeding is not as synchronized and can occur in almost any month. The timing of rut differs by region within the state of Florida and can vary as much as 9 months from one part of the state to another. In north Florida, breeding season shifts progressively later from the eastern part of the state (September) to the western part of the Panhandle (February). Throughout 
peninsular Florida, rut in many areas occurs during the fall (September through October) and winter (November through January), however, there are exceptions, such as the notably late (March) breeding season in west-central Florida. In south Florida the peak of rut activity is July through August. Key deer rut occurs from September through December. To learn more about the breeding seasons across Florida visit https://myfwc.com/media/18766/ deerchron_2019_map.pdf.

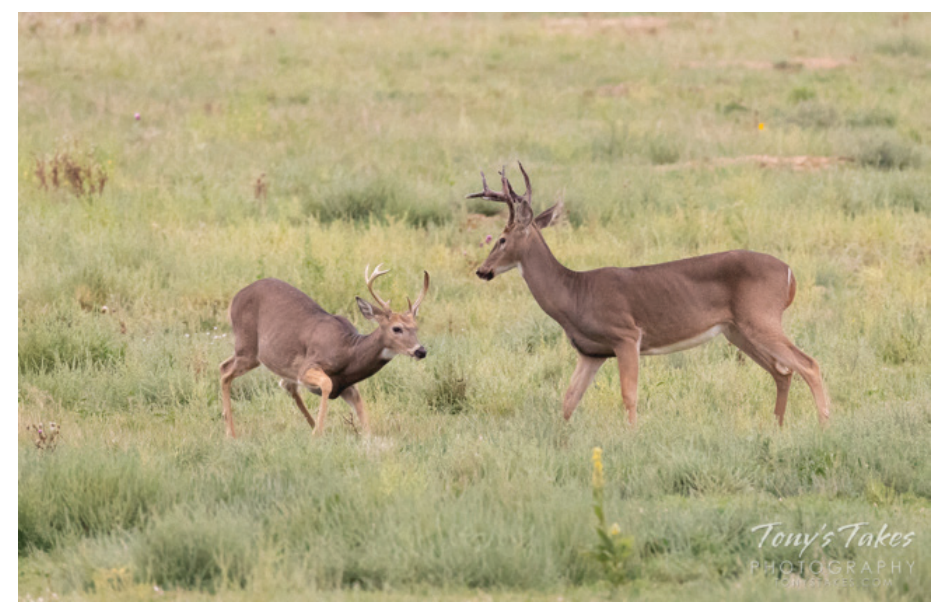

Figure 12. Two bucks sparring to establish dominance during breeding season.

Credits: Tony Takes, https://creativecommons.org/licenses/by-ncnd/2.0/legalcode

This variability indicates that the reproductive patterns of Florida's deer have evolved to unique environmental pressures. For instance, peak periods of fawning in the Everglades in south Florida have been found to occur during the January-March dry season. Fawns from northern states are typically born during June, a period of heavy rainfall and seasonal flooding in south Florida. Does that do not become pregnant during their first estrus will come into estrus again 28 days later. Because of this and due to milder climates, breeding in Florida may occur over much longer periods than seen among northern herds. Depending on the availability of dominant bucks, young ones may not have an opportunity to breed until they are several years old.

Once impregnated, the doe's gestation lasts about 200 days ( 6.5 months). Because of the severe energetic costs of lactation, the birth of fawns is typically correlated to the availability of highly nutritious forage. Although deer pregnancy rates in Florida are usually over 90\%, productivity (fawns per doe) rates of Florida deer are generally lower compared to herds in northern states where more nutrientrich soils provide higher-quality foods. Nutritional status also influences the number of offspring a doe can have.
Most fawns are born on edges of open fields or in thickets (Figure 13). For the first few days after birth, fawns are nursed 2-3 times during daylight hours. Nursing becomes less frequent until they are weaned at about four months. A gland between the two parts of the hoof secretes a scented substance, by which the doe can track her fawn if it wanders off.

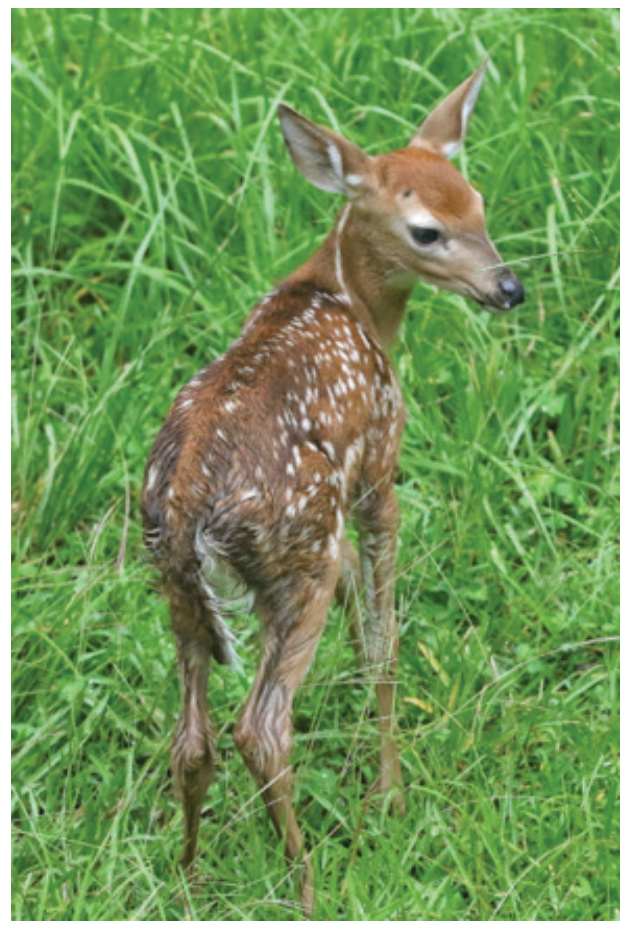

Figure 13. Recently born white-tailed deer fawn.

Credits: Dennis Adair

When fawns are found lying alone, they should not be assumed to be orphaned. Does will often leave fawns unattended while feeding. This behavior reduces noise and movement in the area where fawns are bedded that may attract predators. Does return to nurse and protect fawns after feeding, so fawns found alone should not be assumed to be abandoned. A doe will not abandon her fawn if it has been handled by a human, however, if found, the fawn should be left alone because the doe is undoubtedly close by. They are not panicked by human scent because they encounter human odors regularly. Fawns will stay with the doe through their first year, but are chased off by does just before the birth of new fawns. The yearling females are generally allowed to return shortly after birth of the new fawn, but yearling males typically disperse, sometimes great distances, and rarely rejoin these family groups. Eventually, female offspring will establish a home range near the area where they were born and occasionally associate with related individuals. 


\section{Mortality, Injuries, Diseases, and Predation}

Many deer suffer injury and even death from collisions with automobiles, entanglements in fences, drownings, and other miscellaneous accidents. One study published in 1964 reported an estimated 800 deer killed on Florida highways during that year. The Florida Department of Transportation (DOT) places deer-crossing signs in areas where the frequency of deer collisions with vehicles is relatively high. The purpose of these signs is to warn drivers of this potential hazard so they will proceed with caution.

Nearly all deer collisions with vehicles occur during the hours of darkness. When blinded by headlights, deer can move very abruptly and unpredictably. If you see a deer on a highway right-of-way, slow down and be prepared to stop suddenly. Deer seldom travel alone, and seeing one cross the road should signal the need for extreme caution because other deer are likely present. In many cases, the risk of deer-auto collisions must be managed solely by modifying driver behavior. However, over 45 Key deer, (about 7.5\% of the population) have died from vehicle collisions each year during this decade.

Key deer are adversely affected by another human- caused health problem: hand-feeding of marshmallows and other poor-quality foods. Many individuals of this subspecies are very tame and will eat out of people's hands. When they become habituated to this style of feeding, their nutrient consumption is low which causes poor health and reproductive performance.

Local flooding in the Everglades concentrates deer on high ground and forces them to consume low- quality foods. During these periodic events, many die of malnutrition and starvation.

Other potential causes of injury and poor health are poisonous plants, heavy metals, and pesticides. Approximately 100 species of poisonous plants occur in the southeastern U.S. and every deer habitat has one or more of these plants. Mercury and chromium have been found in live Florida deer but sub-lethal effects are not known. Pesticide residues are known to increase postpartum mortality, slow down development of immature deer, and impair initial conception by young does. However, these impacts have not been documented or studied in Florida.

White-tailed deer are hosts to many parasites and infectious agents. Biologists have documented 120 different parasites, infections, and disease conditions of Florida deer. Although every deer in Florida is not plagued with all 120 disease agents and conditions at one time, the average animal will be host to a number of parasites and infectious agents at any time. Many of these, by themselves, will not cause sickness or death. However, they can cause harm if other factors such as stress and malnutrition weaken an animal's resistance to infection. Simultaneously, infections of more than one agent can have interactive effects on the host that may be considerably more serious than the effects of each of them separately. Several of the diseases and parasites of Florida deer are of public health concern and also can be transmitted to cattle.

A few mammalian predators prey on deer in Florida. Whitetails are the second most common prey next to wild hogs (Sus scrofa) for panthers. Bobcats (Felis rufus) are another important predator. Researchers concluded that 5 of 20 deer found dead in the Big Cypress National Preserve during 1993 were killed by bobcats. During high-water levels in south Florida, when deer are more concentrated, they are also more susceptible to bobcat predation.

Coyotes (Canis latrans) have become more plentiful in Florida during the past decade and likely prey on Florida deer but no studies have examined the impact of this mortality. Black bear (Ursus americanus) occasionally take newborn fawns but do not have a major effect on deer populations. Free-ranging dogs are a primary cause of mortality for Key deer.

\section{Mortality and Injuries}

Mortality of adult deer is primarily from hunting with over 120,000 deer harvested annually, but many deer suffer injury and death from collisions with automobiles, entanglements in fences, drownings, and other miscellaneous accidents. According to a claims analysis by State Farm Insurance for 2017-2018, the likelihood of hitting a deer in Florida is relatively low; in fact, Florida ranks $46^{\text {th }}$ out of the 50 states. (First is West Virginia, which has lead the nation for the past 12 years.) The Florida Department of Transportation (DOT) places deer-crossing signs in areas where the frequency of deer collisions with vehicles is relatively high. The purpose of these signs is to warn drivers of this potential hazard so they will proceed with caution.

Nearly all deer collisions with vehicles occur during the hours of darkness. When blinded by headlights, deer can move very abruptly and unpredictably. If you see a deer on a highway right-of-way, slow down and be prepared to stop suddenly. Deer seldom travel alone, and seeing one cross the road should signal the need for extreme caution because 
other deer are likely present. In many cases, the risk of deer-auto collisions must be managed solely by modifying driver behavior. However, over 45 Key deer (about 7.5\% of the population) have died from vehicle collisions each year during this decade.

Key deer are adversely affected by another human-caused health problem: hand-feeding and scavenging for poorquality foods. Many individuals of this subspecies are very tame and will eat out of people's hands. When they become habituated to this style of feeding, their nutrient consumption is low, which causes poor health and reproductive performance.

\section{Diseases}

White-tailed deer are hosts to many parasites and infectious agents. Since 2011, biologists have documented over 120 different parasites, infections, and disease conditions of Florida deer. Although every deer in Florida is not plagued with all disease agents and conditions at one time, the average animal will be host to a number of parasites and infectious agents at any time. By themselves, most of these will not cause sickness or death. However, they can cause harm if other factors such as stress and malnutrition weaken an animal's resistance to infection. Simultaneously, infections of more than one agent can have interactive effects on the host that may be considerably more serious than the effects of each of them separately. Several of the diseases and parasites of Florida deer are of public health concern and also can be transmitted to cattle.

Two important viruses are epizootic hemorrhagic disease (EHDV) and bluetongue (BTV) (for more information click here). Both are considered to be infectious but noncontagious diseases and are endemic to Florida. Biting midges ("no-see-ums") transmit these diseases, and clinical signs include disorientation, lethargy, bleeding from the mouth or nose, facial swelling and salivation, weakness, altered gait, fever, anorexia, and respiratory distress. A sign specifically for BTV is a deer having a bruised ("blue") tongue with lesions on the tongue or mouth. Internally, hemorrhaging (ruptured blood vessels) and necrosis (cell death) can occur. Death of an individual may occur suddenly and with little to no external signs. The disease can also be chronic (long lasting), with deer surviving the infection. Both diseases are becoming more prevalent due to expanding vector range, movement of captive animals, and overwintering of the virus, resulting in year-round exposure. EHDV and BTV are considered seasonal diseases, with a majority of deaths occurring August-November in Florida. Diagnostic tests are available, such as blood testing, for live and dead individuals. Other than supportive care, there is no specific treatment for the diseases, though reducing exposure to midges may be valuable in reducing prevalence. There are no effective vaccines. These viruses do not infect humans.

Theileriosis is another globally significant disease. It is caused by the protozoan parasite Theileria cervi and spread by the lone star tick. Protozoan are single cell organisms that often live and replicate within the living cells of their hosts, commonly in blood cells, causing death of cells and sometimes impairing physiological function of the host. It is considered common and widespread in Florida whitetailed deer, with a study in Gadsden County determining that $97.6 \%$ of wild deer and $40.4 \%$ of captive deer sampled had the infection. Infection is typically subclinical (no obvious signs) in deer, unless exacerbated by stress from poor nutrition, high pen density, other illnesses, or from being transported to a new location. External signs include a coarse and brittle coat and a staggered gait, while internally the deer might be anemic, have tissue damage, or have parasite infestation of tissues such as the lymph nodes or liver. Infection is diagnosed through blood tests. Babesiosis is similar to Theileriosis in that it is also transmitted by a protozoan parasite (Babesia odocoilei) that is spread by the deer tick. Again, this disease is subclinical unless aggravated by stressors such as the ones listed above. There is no vaccine available for deer for either disease, and these parasites are not known to infect humans.

Plasmodium odocoilei is another protozoan parasite that infects white-tailed deer. It is transmitted by mosquitoes and causes deer malaria. The parasite is also considered common and widespread and is endemic to Florida. A study in the panhandle showed that $21 \%$ of farmed white-tailed deer fawns sampled were infected at some point during their first year of life. Diagnosis is through blood sampling of live and dead individuals, and though it is considered a chronic infection, individuals have been known to clear the infection and survive. Only since 2016 has there been definitive results of deer infected with malaria, so more studies need to be done to determine the relationship it might have with deer, humans, and other animals.

Chronic wasting disease (CWD) is a contagious disease caused by prions, which are abnormal forms of proteins from central nervous tissue. Prions infect the brains of deer and cause death due to chronic weight loss. Besides wasting, other signs include listlessness, lowering of the head, blank facial expressions, and repetitive movements. There is no evidence that people can contract this disease, but it is recommended to stay away from infected animals and 
not consume meat from animals known to be infected with CWD. In addition, hunters should take certain precautions when field dressing or processing deer or elk in areas where CWD is found. FWC has not found evidence of CWD in captive or wild white-tailed deer in Florida. However, because the disease has been found in deer in 26 other states in the United States as well as 3 provinces in Canada, it is illegal to bring live deer into Florida. In addition, it is illegal to bring into Florida the carcass of any cervid (deer, elk, moose) from any state where CWD has been detected. Hunters can bring back deboned meat, finished taxidermy mounts, tanned hides, cleaned skulls, antlers, or teeth into Florida, so long as all soft tissue has been removed before importation. When an infected deer is found, the goal is to eradicate the entire population in the area, wild or captive, to prevent further spread of the disease, however, this is not always possible. For more information on CWD monitoring in Florida and for a list of regulations, please see: https://myfwc.com/research/wildlife/health/white-tail-deer/ cwd/. To report a sick deer or deer that died of unknown causes, please call the CWD Hotline (866) CWD-WATCH (293-9282).

\section{Predation}

A few mammalian predators prey on deer in Florida. Whitetails are the main prey species of the Florida panther. Bobcats (Felis rufus) are another important predator. Researchers concluded that 5 of 20 deer found dead in the Big Cypress National Preserve during 1993 were killed by bobcats. During high-water levels in south Florida, when deer are more concentrated, they are also more susceptible to bobcat and panther predation.

Coyotes (Canis latrans) have become more plentiful in Florida during the past decade and likely prey on Florida deer, especially fawns, but no studies have examined the impact of this mortality in Florida. Black bear (Ursus americanus) occasionally take newborn fawns but do not appear to have a major effect on deer populations in Florida. Free-ranging dogs are a primary cause of mortality for Key deer. However, it is important to note that predator-prey relationships fluctuate. As the prey populations increase in relation to high resource years, there is more food available for predators and predator populations increase. Then as predator populations increase and capture more prey, the prey population will eventually decrease, especially in poor resource years, followed by a decrease in the predator population. Removal of large predators has been shown in some cases to lead to an increase in deer and other herbivore populations, but that in turn has unforeseen effects, often damaging plant populations and eventually modifying habitats. The loss of predators in ecosystems can have unpredictable results, and the conservation of all animals helps maintain complex ecological relationships that exist among predators and prey and between herbivores and plant communities. The removal of predators from much of the nation's landscape has allowed species such as whitetailed deer to drastically increase in population abundance and become pest species.

\section{Management and Harvest Information}

The FWC is lead manager on over 0.5 million hectares ( 1.3 million acres) of land and assists cooperators with wildlife management on 1.8 million hectares (4.5 million acres). The goal of the FWC's deer-management program is to properly use the species as a natural, renewable resource in such a manner as to maintain herds in a condition of quality health and reproductive performance.

To maintain a certain population level, mortality caused by disease, predation, accidents, and harvesting must not exceed the number of deer born each year. When densities of deer become too high for the habitat to support, deer become very destructive to habitats. This negatively affects the health of deer as well as other species, and, unless deer numbers are reduced, the herd will destroy the food base upon which it depends and may decline to very low numbers. Consequently, the management of deer through harvest of both sexes is often necessary, provides economic return for local communities, and provides funding to state programs that benefit all wildlife.

Because one buck can mate with several does during one season, harvesting bucks has a smaller impact on population growth. However, over-harvest resulting in low densities of mature bucks can have negative impacts on productivity due to the energy and time required for relatively few mature males to mate with large numbers of females. Consequently, the mating season can be prolonged and some females may not be bred. Harvesting does may be important to maintain a healthy herd and reduce local densities where the population is greater than the habitat's carrying capacity.

In the early 1980s, the FWC began to allow the harvesting of does as well as bucks. The commission conducted a survey to determine deer harvest in Florida by deer management units (DMU) during the 2017-2018 hunting season (see more on deer management units below). The survey reported an estimated total of 94,594 deer were 
harvested from DMUs during the 2017-2018 hunting season. Of these, about $63 \%$ were bucks.

Annually, the FWC oversees the monitoring of deer condition and population trends. Florida Fish and Wildlife Commission biologists collect data at check stations during hunting seasons by aging and weighing harvested deer and measuring antlers. The biologists also conduct numerous surveys and research throughout the year to estimate population trends, sex ratios, and fawns produced per doe. These and other data are used to evaluate the condition of a deer herd and its response to hunting and to establish suitable harvest levels and hunting seasons. In addition to information on deer, management decisions must take into account the effects of recent environmental conditions on habitat quality and the needs of native predators that rely on deer for survival.

Because the quality of Florida's deer habitats are so diverse and the time of rut varies across the state, determining harvest regulations that will maintain healthy deer populations while providing the best recreational opportunities for hunters is extremely challenging. Hunting technique is another variable to consider. Due to the variability in deer populations, habitat, and time of rut across Florida, the state is divided into four deer management units (DMU) or harvest zones: Northwest-Zone D, Northeast/Central-Zone C, Central-Zone B, and South-Zone A. With the exception of the smallest zone (B), all other DMUs are subdivided into smaller DMUs to allow flexibility in deer management based on stakeholder preferences.

The white-tailed deer is defined as a game mammal in the state of Florida, and as such it is protected by several statutes and rules. Some of the related illegal activities described in Florida Statute 372.99 include: 1) killing or possessing a freshly killed deer during the closed season; and 2) taking or attempting to take a deer in or out of season by use of gun and light. In addition, there are antlersize regulations that vary depending on the DMU location; see link below for more details on hunting regulations.

Rules 39.12 and 39.13 in the Florida Administrative Code address issues such as baiting, hunting with dogs, hunting hours, bag limits, methods of taking, open season, sale of venison, tagging, and transporting.

All decisions and rules for hunting of white-tailed deer in Florida are determined by the FWC and published each year in a hunting regulations handbook available free of charge in sporting goods stores and at many state and county services offices. You can also learn more at https:// myfwc.com/hunting/deer/.

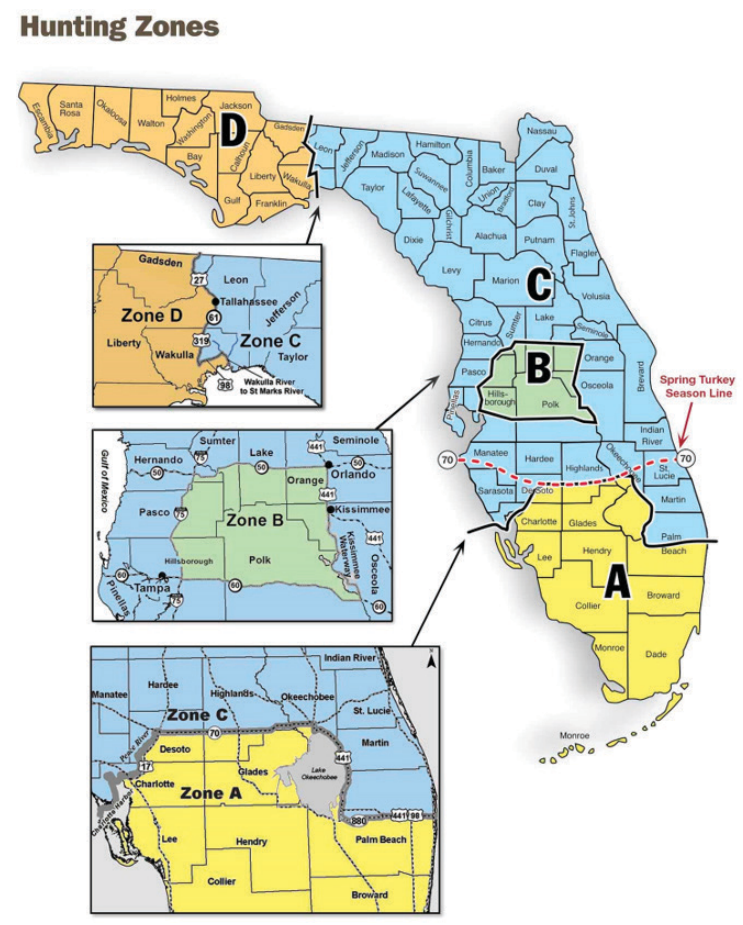

Figure 14. FWC deer management units (DMU).

Credits: FWC, https://myfwc.com/hunting/season-dates/zone-map

\section{Suggested Readings}

Bellis, E. D., and H. B. Graves. 1971. "Collision of vehicles with deer studied on Pennsylvania interstate road section." Highway Res. News 42:13-17.

Brown, R. D. (ed.). 1983. Antler development in the Cervidae. Caesar Kleberg Wildlife Institute, Kingsville, TX.

Crawford, D. A., M. J. Cherry, B. D. Kelly, E. P. Garrison, D. B. Shindle, L. M. Conner, R. B. Chandler, and K. V. Miller. 2019. "Chronology of reproductive investment determines predation risk aversion in a felid-ungulate system." Ecology and Evolution 9:3264-3275.

Curtis, P. S., and M. E. Richmond. 1992. "Future challenges of suburban white-tailed deer management." Trans. N. Amer. Wildl. \& Nat. Res. Conf. 57:104-114.

Gerlach, D., S. Atwater, and J. Schnell (eds.). 1994. Deer. Stackpole Books, Mechanicsburg, PA. 384 pp.

Goss, R. J. 1983. Deer antlers: regeneration, function, and evolution. Academic Press, New York.

Halls, L. K. 1984. White-tailed deer: ecology and management. Stackpole Books, Harrisburg, PA. 
Harlow, R. F. 1959. "An evaluation of white-tailed deer habitat in Florida." Tech. Bull. 5, Fl. Game \& Fresh Water Fish Comm., Tallahassee, FL. 69 pp.

Harlow, R. F. 1961. "Fall and winter foods of Florida whitetailed deer." Q. J. Fl. Acad. Sci. 24:19-38.

Harlow, R. F. 1972. "Reproductive rates of white-tailed deer in Florida." Q. J. Fl. Acad. Sci . 35:165-170.

Harlow, R. F., and F. K. Jones (eds.). 1965. "The white-tailed deer in Florida." Tech. Bull. 9, Fl. Game \& Fresh Water Fish Comm., Tallahassee, FL. 240 pp.

Henderson, F. R., and C. Lee. 1992. "Controlling deer damage." Coop. Ext. Serv. Fact Sheet C-728, Kansas State Univ., Manhattan, KS. 8 pp.

Hygnstrom, S. E., and S. R. Craven. 1988. "Electric fences and commercial repellents for reducing deer damage in corn fields." Wildl. Soc. Bull. 16:291-296.

Kammermeyer, K., and R. Thackston. 2019. "Deer \& Turkey Management: Beyond Food Plots." Kent Kammermeyer consulting, LLC. http://www.deerconsulting.com/beyondfoodplots.aspx

Logan, T. H., and A. Egbert. 1981. The Florida deer story. Fl. Wildl . (Nov.-Dec.).

Richter, A. R., and R. F. Labisky. 1985. "Reproductive dynamics among disjunct white-tailed deer herds." Fl. J. Wildl. Manage. 49:964-971.

Severinghaus, C. W., and E. L. Cheatum. 1969. The life and times of the white-tailed deer. Pp. 57-186 In: W.P. Taylor, (ed.). The Deer of North America. Harrisburg, PA: Stackpole Book.

Smith, T. R., C. G. Hunter, J. F. Eisenberg, and M. E. Sunquist. 1996. Ecology of white-tailed deer in eastern Everglades National Park-An overview. Fl. Mus. Nat. Hist. 39:141-172.

VerCauteren, Kurt C., and Michael J. Pipas. 2003. A Review of Color Vision in White-Tailed Deer. Wildlife Society

Bulletin, vol. 31, no. 3, 2003 